\title{
Growth Intention and Its Impact on Business Growth amongst Smes in South Africa
}

\section{Dr Brownhilder Ngek Neneh}

\author{
Department of Business Management, University of the Free State \\ Bloemfontein, South Africa 9301 \\ Email : brahilder@gmail.com
}

\section{Dr Johan Vanzyl}

Department of Business Management, University of the Free state Bloemfontein, South Africa 9301

\author{
Doi:10.5901/mjss.2014.v5n20p172
}

\begin{abstract}
Growth is generally perceived as a good goal for businesses because it is an important measure of business success and key driver to the creation of wealth, employment, and economic development in every country around the world. Nevertheless, studies depict that many SME owner are not interested in growth or deliberately refrain from pursuing growth and it is also unclear as to what happens to entrepreneur's growth intentions subsequent to the launch of a venture. This study had as objectives to find out which factors determine the growth intention amongst existing business owners and the impact growth intention has on the actual growth of their SMEs. This study identified some factors (locus of control and self-efficacy, prior family business exposure, level of education, entrepreneurship education, need for achievement, tolerance of ambiguity and uncertainty and procedural requirements for business registration) to significantly affect the growth intentions of entrepreneurs in South Africa. This study also established that growth intentions were significantly related to actual firm growth in terms of sales growth and asset growth. Thus policy measures should put in place support programs that will promote a culture of growth oriented thinking amongst SME owners as a means of fostering growth in the SME sector.
\end{abstract}

Keywords: Growth Intention, firm growth, SME, South Africa

\section{Introduction}

The role of intention has been extensively studied by researchers across the globe because of its importance to the development of an economy through job creation and wealth creation (Yeboah, Kumi and Baffour, 2013). The intention to have an entrepreneurial career before actually establishing the business is the focus of entrepreneurship because of its importance as a starting point of new venture creation. While, entrepreneurial intention is the primary step towards the creation of a new venture in the entrepreneurial process (Van Gelderen, Brand, van Praag, Bodewes, Poutsma \& van Gils, 2008); Sadler-Smith, Hampson, Chaston and Badger (2003) points out that an essential characteristic of entrepreneurial behavior is the intention to grow the business. Dutta and Thornhill (2008:310) define growth intentions as "being the entrepreneur's goals or aspirations for the growth trajectory she or he would like the venture to follow". Some studies (Gundry \& Welsch, 2001; Welsch, Price \& Stoica, 2013) have observed that entrepreneurs vary considerably in their intentions to grow their business. Levie and Autio (2013) established that in small businesses, the motivations of the owner and the business are intertwined. Consequently, the growth intentions of the entrepreneur for their business are a reflection, in at least, as part of their own motivations for running the business.

Researchers (Mappigau \& Maupa, 2013; Torres \& Watson, 2013; Saddle- Smith et al., 2003; Krueger, Reilly \& Carsrud, 2000) argue that the concept of an entrepreneur's intention can be extended to existing businesses (i.e. businesses that have gone beyond the inception stage). This is because the concept of entrepreneurship does not end when a business is created, but also includes the intention to grow the business. Orser, Hogarth-Scott and Riding (2000) and Dutta and Thornhill (2008) stress that small business growth is non-linear over time and thus expects that the entrepreneur's initial intention to launch a business and attain a certain level of growth in business during the formative years to evolve as the business matures. Nevertheless, Dutta and Thornhill (2008) found that entrepreneur's initial growth intentions are heterogeneous, due to the factors that influence intention formation and also the differences in initial conditions across the business. Stenholm (2011) and Toivonen, Stenholm \& Heinonen (2006) found a clear 
distinction between the actual growth of a business and growth intentions, by stating that intentions are only one of the fundamentals for SME growth. Wiklund and Shepherd (2003) observed that the growth intentions of entrepreneurs are positively related to actual growth of the business.

SME growth has been identified as a key driver to the creation of wealth and employment and economic development in every country around the world (Davidsson, Achtenhagen, \& Naldi, 2010; Bosma, van Praag \& De Wit, 2000). Also, growth is an important measure of a business success. Wiklund, Davidsson and Delmar (2003) stress that SME growth is the most important source of new jobs. Davidsson et al. (2010) indicate that it is through growth that SMEs can become lager organizations and growth is closely linked to job creation, which is vital for the success of the economy (Bosma et al., 2000). Dobbs and Hamilton (2007) accentuate that growth is closely related to the creation of jobs and that rapidly growing SMEs create employment opportunities in society which is vital for the success of the economy. However, Gundry and Welsch (2001) draw attention to the fact that SMEs do not grow and that entrepreneurs vary substantially in their intentions to grow their business. Welsch, Price and Stoica (2013) found that SME owners are usually more concerned about their survival rather than growth. Levie and Autio (2013) observed that achieving growth is very difficult and requires effort, and if entrepreneurs do not intend to grow their businesses, their businesses will be less likely to grow and the growth intention will be less likely to materialize. These authors further classified the factors that affect SME growth and growth intention into the individual characteristics, business characteristics and environmental characteristics. Tan, Menkhoff, and Chay (2007) and Davidsson et al. (2010) attributed the lack of growth to the founder specific characteristics of the entrepreneur, as many SME owner-managers are either not interested in growth or deliberately refrain from pursuing growth.

Previous studies on intention have mostly focused on understanding its importance and impact on individuals' and graduate students intention to start businesses (Fatoki, 2013; Agbim, Oriarewo \& Owocho, 2013; Fini, Grimaldi \& Sobrero, 2009; Sivarajah \& Achchuthan, 2013). Also, empirical studies on entrepreneurs and firm growth have generally focused on the entrepreneurs' motives towards growth (Autere \& Autio, 2000; Davidsson et al., 2010). In South Africa, studies on intention have focused on graduate student's intention to start businesses and used student samples instead of using the actual samples of entrepreneurs (Fatoki, 2014; Fatoki, 2013; Fatoki, 2010; Scheepers, Solomon \& de Vries , 2009; Tshikovhi \& Shambare, 2012; Malebana, 2014). Fatoki (2013) used a sample of immigrant entrepreneurs in South Africa to determine the factors that affected their growth intention; however, he did not attempt to investigate whether their growth intentions were related to the actual growth of their businesses. Also, some known factors (e.g. psychological factors such as risk taking propensity, self-efficacy etc) that have been established to affect growth intentions in other studies (Levie and Autio, 2013) were not investigated by Fatoki (2013). Growth intentions can be of no use in terms of economic development if such intentions are not acted upon. As such, an understanding of how growth intentions impact on the actual SME growth can significantly add value to the existing literature on SME growth in South Africa. It can also have implications for job creation, economic growth and poverty reduction as the government policies for economic development are highly dependent on the vibrant potential that is expected to emerge from the SME sector with regards to creation of decent jobs. This study thus has as objectives to find out which factors determine the growth intention amongst existing business owners and the impact growth intention has on the actual SME growth.

This study is particularly important because it is expected that the intention to start up a business is also antecedent to other steps in the process of entrepreneurship, such as the growth of the business. As such one, it is expected that the both the decision to start a business and the decision to growth a business originate from a person's entrepreneurial intention. Also, given that providers of capital, customers, suppliers and venture employees, are affected by the entrepreneur's ability to facilitate venture growth, an understanding of the determinants of growth intentions, which may change over time, will have significant consequences for anyone with a stake in a growing business.

\section{Literature Review}

\subsection{Growth Intention}

In economic theory, while growth is viewed as a natural phenomenon that occurs until profit is maximized, nevertheless, in reality, not all SMEs owners want to grow their businesses to maximize profit (Verheul and van Mil, 2008). While some entrepreneurs are determined to grow their businesses into larger businesses, and attain substantial growth, many SME owner-managers are not interested in growth or deliberately refrain from pursuing growth (Gundry \& Welsch 2001, Wiklund, et al, 2003). Several theories such as the Expectancy Theory (Vroom's, 1964); Expectancy Value Theory of Attitudes (Fishbein and Ajzen's, 1975), Theory of Planned Behavior (Ajzen's, 1991) and Psychological motivation theory (Davidsson, 1989) have been used to understand and explain an individual's intention to pursue growth. Wiklund and 
Shepherd (2003) make a conclusion by stating that the pursuit of growth is a deliberate individual decision of the entrepreneur.

It is indisputable that if entrepreneurs do not intend to grow their businesses, their businesses are less likely to grow (Levie and Autio, 2013). Studies by the Global Entrepreneurship Monitor (Autio, 2007) found out that only 10\% of nascent and new entrepreneurs think they will create $70 \%$ of all job creation predicted by their cohort over a five year horizon. This finding is supported by Blackburn, Kitching, Hart, Brush and Ceru (2008) who established that high-growth businesses are more likely to have planned for their growth, or achieved or exceed their planned growth. Mappigau and Maupa (2013) note that entrepreneurs' intentions play a critical role in understanding the process of entrepreneurship in relation to the growth of the business. Terjesen and Szerb (2007) adds that growth is a combination of what the entrepreneur wants, with what is possible given the critical resources and skills of the entrepreneur and available opportunities. Wiklund and Shepherd (2003) and Verheul and van Mil (2008) point out that while the act of starting up a company is a choice, SME growth and growing the business should no longer be considered as a natural phenomenon as the decision to grow depends upon perceived opportunities, skills and the entrepreneur's willingness to do so. Krueger (2000) emphasizes that very little is known about the changing intentions, while, Dutta and Thornhill (2008) assert that it is unclear as to what happens to growth intentions subsequent to the launch of a venture. Thus it becomes necessary to find out what happens to growth intentions after a venture has been created, given that the challenges faced by small businesses are not constant over time but vary between the start-up and growth stages.

\subsection{Determinants of growth intention}

Researchers (Vehuel \& Van Mill, 2008; Terjesen \& Szerb, 2008; Dutta \& Thornhill 2008; Karadeniz \& Ozçam, 2010; Levie \& Autio, 2013; Fatoki, 2013) classified the factors that determine the growth intention of business into several categories: entrepreneur demographics (gender, age, education, family experience); the entrepreneurs personal context ( startup motivation (active risk take, desire to succeed, desire to be one's own boss and the desire to be independent, opportunity recognition); firm attribute (size and innovation); the individual skills of entrepreneur (managerial skills, technical skills, practical skills, career experience, serial entrepreneurship and patenting); psychological characteristics (risk taking propensity, the need-for-achievement, goal setting, self-efficacy and tolerance of ambiguity) and external environmental factors such as government policies (availability of government's assistance, training programs and support service, taxes, procedural requirements for registration), organizational factors (innovative climate and incentives) and characteristics of the local context such as the availability of externalities, logistic infrastructure and financial investors. These factors together influence the entrepreneur's decision to initiate a business as well as their intention to grow the business (Mappigau \& Maupa, 2013; Shane \& Khurana, 2003; Torrres, \& Watson, 2013).

With regards to the demographic factors, studies have provided mixed results. For example Karadeniz and Ozcam (2010) established that gender and education have significant and positive effects on the growth intentions of entrepreneurs. They observed that male owned businesses were more likely to grow than female-owned businesses. This is because female entrepreneurs are usually more risk adverse than their male counterparts, thus suggesting that gender has a positive impact on growth intention. However, Levie and Autio (2013) found that gender showed no consistent impact on growth intention. Hisrich and Drnovsek (2002) pointed out that managerial competencies (education, knowledge of the industry, start-up experience and managerial al experience) had a positive impact on the growth intention of the business. Karadeniz and Ozcam (2010) found that the growth intentions were higher among entrepreneurs who are male and more educated. Lee, Chang and Lim (2005) pointed out that education is one of the most important factors distinguishing entrepreneurs from non-entrepreneurs. Levie and Autio (2013) established that a person's education levels and prior entrepreneurial experience had a small but robust positive effect on growth intention. Crant (1996) observed that being raised in a family that is entrepreneurial greatly impacts the individuals' growth intentions.

Furthermore, with regards to the entrepreneurs personal context Papadaki and Chami (2002) and Karadeniz and Ozçam (2010) elucidate that start up motivation positively impact on growth intention. Vivarelli (2004) and Block and Sandner (2009) established that the performance of business started up by entrepreneurs based on a positive entrepreneurial thinking was higher than business driven by defensive reason (i.e. escape from unemployment). Fatoki (2013) established a significant and positive relationship between the motivation (necessity and opportunity) and growth expectation. Verheul and van Mil (2008) and Terjesen and Szerb (2007) established that entrepreneurs that started a business because of an opportunity were more likely to result into growth ambition than entrepreneurs who started a business because there was no other option (necessity). Moreover, with regards to psychological factors, Levie and Autio (2013) revealed that there is a direct relationship between growth intention and risk-taking propensity, a positive 
relationship between need for achievement and growth intention, and a positive relationship between self-efficacy and growth intention, reflecting the confidence that comes from success. Verheul and van Mil (2008) found that entrepreneurial self-efficacy affects the growth ambition. Cassar (2007) established that entrepreneurs who are risk tolerant are more likely to have an ambition to grow their businesses.

In terms of external factors, Fairlie (2009) identified government policies to be one of the key external factors that impede the entrepreneurial activities of Maori entrepreneurs of New Zealand. Zapalska, Dabb, and Perry (2003) observed that excessive number of government policies and procedures such as procedural requirements for registration, entry barriers and the restrictions on imports and exports turn to have much more negative effects than positive effects on entrepreneurship. Tomlin (2008) identified taxes as a government policy that impedes entrepreneurial activity. He argued that taxes and complex tax system put excessive pressure on SMEs, as the resources directed towards tax compliance are resources that could be used for reinvestment in to the business, to facilitate future growth. As such, he is of the opinion that reducing the tax rate and compliance cost will increases the profit margin of SMEs. Moreover, the availability of government's assistance, training programs, and support services is another policy by most governments all around the world where they provide direct financial assistance and support programmes to make loans available to SMEs and business opportunities. For example, in the UK, the Bank of England invests in SMEs with government and private sector money through; the start-up loan scheme, business angel co-investment fund and the business finance partnership (Department for Business, Innovation \& Skills HM Treasury, 2014). Moreover, in South Africa, SEDA's Strategic Plan for the 2011/2012 and 2013/2014 period placed emphasis on providing assisting to SMEs to access financing and business opportunities (Mthente Research and Consulting Services, 2012). Studies by Mazanai and Fatoki (2011) established that SMEs that are aware and use the support programmes have improved access to debt finance. Sadeghi et al (2013) stress that a positive government policies create a friendly entrepreneurship environment that encourages existing and potential entrepreneurs to take risk and start up their own businesses.

\subsection{SME growth}

Over the past decades, researchers and policy-makers around the world have placed considerable attention on the growth of SMEs. SME growth has been one of the most widely studied topics in entrepreneurship and economic literature and it is a phenomenon that inevitably happens over time. Sexton (1997:97) asserts that "growth is the very essence of entrepreneurship", thus making the relationship between growth and entrepreneurship a relevant question. With regards to the determinants of SME growth, Levratto, Tessier and Zouikri (2010) observed that factors such as firm's resources, human capital (age, experience) and the environmental and market characteristics play important roles in SME growth. Also, Sirec and Mocnik (2010) established the components of SME growth to be employee growth, asset growth and sales growth. Sales growth is considered a very important and popular determinant of SME growth because entrepreneurs measure growth through business sales (Shepherd and Wiklund 2009; Isaga, 2012; Achtenhagen, Naldi \& Melin, 2010). Also, policy makers regard sales growth as an important determinant for income generation (Shepherd \& Wiklund 2009). Jansen (2009) explicate that it is the increase in sales that makes it possible for businesses to invest in additional factors of production such as equipment and employees, which will in turn result in raising the profits of the business. Employment growth is also considered as an important aspect of firm growth since studies on government policy measure growth in terms of employment (Shepherd and Wiklund, 2009). Fatoki (2013) explicated that employment growth is an important measure of firm growth in South Africa due to the country's current eagerness for job creation, which has been identified as a top priority by policy makers. Studies (Shepherd and Wiklund, 2009; Levie \& Autio, 2013) have also highlighted the importance of measuring firm growth in terms of the relative increase in the assets of the business. Growth in assets can provide entrepreneurs with the collateral security for obtaining external financing which can be used for fostering the growth of their businesses.

Based on the previous studies and theories stated above, this study developed a theoretical framework (see Figure 1) to guide the empirical investigation. 


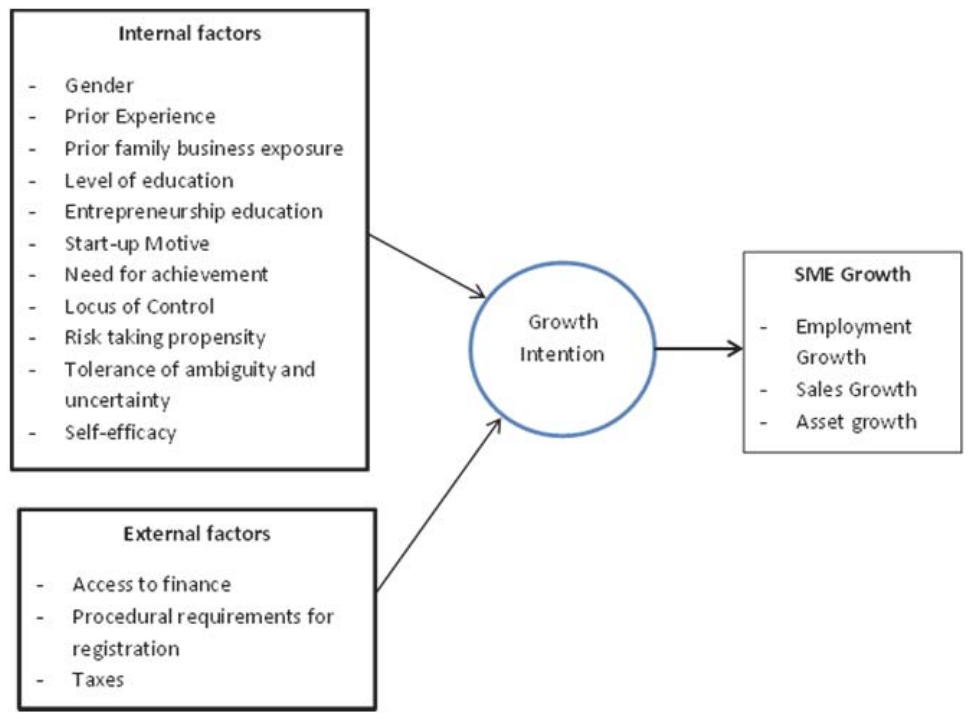

Figure1: The theoretical model for the study

\section{Methodology}

\subsection{Research Design}

This study employed a questionnaire survey approach to find out which internal and external factors determine the growth intentions of existing entrepreneurs, and how their growth intentions impacts on the actual SME growth. Self-administered questionnaires were used for the study and they were pretested twice through structured interviews with three different groups of six SME owners and they findings were used to restructure and eliminate blurred question. The questionnaire was structured to include the self-reported measures of internal and external factors, growth intention, and SME growth (sales growth, employment growth and asset growth).

\subsection{Population Sample}

The population for the study comprised of entrepreneurs found in the Mangaung Metropolitan Municipality in the Free State Province in South Africa (Bloemfontein, Botshabelo and Thaba'Nchu). The researcher obtained a list of contact details of entrepreneurs from notable organizations (Free State development Corporation (FDC) and Small Enterprise Development Agency (SEDA) and contacted them at their various business locations to administer the questionnaires, using the simple random sampling technique. A total of 400 questionnaires were issued of which 200 were fully completed and returned. The questionnaires were administered to owner-managers who were actively involved in the business day-to-day operations. Owner mangers were used because the researcher believes their perceptual measures could be valid in establishing the internal and external factors that affect growth intentions and SME growth.

\subsection{Measures}

\subsubsection{Growth Intention}

Most studies (Karadeniz \& Ozçam, 2010; Mappigau \& Maupa, 2012; Fatoki, 2013) have measured growth intentions in terms of an entrepreneur's willingness to either increase the number of employees or sales within a specified time period. It is evident from prior studies (Sadler-Smith et al., 2003; Torres \& Watson, 2013) that the intention to grow a business is an essential characteristic of entrepreneurial behavior; however, Krueger et al. (2000) argue that entrepreneurs mostly act on intentionality when they perceive that critical resources are available. Also, even with the availability of critical resources, only entrepreneurs with a growth intention will most likely direct the resources towards growing the business, 
as studies (Wiklund, et al, 2003; Tan et al., 2007; Davidsson et al., 2010;) have shown that entrepreneurs without growth intentions are either not interested in growth at all or deliberately refrain from pursuing growth. Following this argument, this study adopted the intentionality measure by Torres and Watson (2013) which determines an entrepreneur's intention to grow the business based on the assumption that critical resources are available. The adopted measure composed of six items in which the respondents were asked to assume that they have received a one million rand grant to use at their discretion. The respondents were then asked to assign a percentage of the money to the following six options: (1) pay suppliers, (2) pay debt, (3) buy out a business, (4) grow the business, (5) start new business, (6) deposit in the bank. Following Torres and Watson (2013), the intention to grow a business was measured by the sum of percentages assigned to items 3,4 , and 5.

\subsubsection{SME growth}

Following prior studies (Sirec \& Mocnik, 2010; Shepherd \& Wiklund, 2009; Isaga, 2012; Achtenhagen, Naldi \& Melin, 2010; Levie \& Autio, 2013), the actual SME growth was measured in terms employment growth, sales growth, and asset growth. Self-reported data on the three components of firm growth was obtained by means of a questionnaire. The respondents were provided with items in which they indicated whether their business has either increased, stayed the same or decreased from the time of inception for each of the three components of SME growth.

\subsubsection{Independent variables}

Demographic information and information on the internal and external factors were captured by means of self-reported data in the questionnaire. Items for gender, level of education, prior experience, family business exposure, and entrepreneurship education were straight forward. The psychological factors such as risk taking propensity, self-efficacy, locus of control, and tolerance of ambiguity and uncertainty were captured using a set of 5-point Likert scale format questions adopted from prior studies (Weber, Blais, \& Betz, 2002; Zhao et al., 2005, Fini et al, 2009; Chen et al., 1998; Neneh, 2012). The external factors (access to finance, taxes, and procedural requirements) were also captured using a 5-point Likert scale in which the respondents indicated the extent to which each of the factors affected their business operations.

\section{Results and Discussion}

\subsection{Descriptive Information of Respondents}

A total of 200 SME owner-managers fully completed and returned the questionnaires which were then subject to analysis. Fifty seven percent of the respondents were male while forty three percent were females. The low percentage of females could possibly be attributed to the gender related barriers for becoming an entrepreneur (Verheul, Thurik, Grilo \& van der Zwan, 2012). Forty two percent of the respondents had prior experience before stating their business, and sixty eight percent came from a family with an entrepreneurial background. More than fifty percent of the entrepreneurs had only attained an educational level up to matric. Also, thirty nine percent of the respondents had taken a course in entrepreneurship. In terms of start-up motives, twenty one percent were opportunity based entrepreneurs while seventy nine percent were necessity entrepreneurs. This is similar to Fatoki (2013) who found that eighty two percent of the respondents in his study were necessity entrepreneurs. The factors that were captured on a 5-point Likert scale are presented on Table 1 below.

Table 1: Descriptive statistics of variables

\begin{tabular}{|l|c|c|c|c|c|c|}
\hline \multicolumn{1}{|c|}{ Factor } & Mean & Std. Dev & Skewness & Kurtosis & N of items & Cronbach's Alpha(a) \\
\hline Need for achievement & 2.10 & 0.8867 & 0.822 & 0.633 & 4 & 0.81 \\
\hline Locus of control & 2.14 & 0.8862 & 0.648 & 0.239 & 4 & 0.72 \\
\hline Risk Taking Propensity & 2.52 & 1.0483 & 0.164 & -.0578 & 3 & 0.73 \\
\hline Tolerance of Ambiguity & 2.34 & 0.9979 & 0.581 & 0.040 & 3 & 0.80 \\
\hline Self-efficacy & 1.84 & 0.9295 & 1.309 & 1.554 & 3 & 0.87 \\
\hline Access to finance & 2.22 & 1.027 & 0.627 & 0.186 & 1 & None \\
\hline Procedural requirements & 2.28 & 1.135 & 0.661 & -0.058 & 1 & None \\
\hline \multicolumn{1}{|c|}{ Taxes } & 2.21 & 0.985 & 0.395 & -0.188 & 1 & None \\
\hline
\end{tabular}


The factors in Table 1 were captured using a five point Likert Scale. For the factors that had more than one variable, a reliability and consistency test (Cronbach's Alpha) was carried out in order to eliminate any incongruous variables. The Cronbach's Alpha (a) values for all the constructs was greater than 0.7 which is acceptable based on the rule of thumb (George \& Mallery, 2003). For the physiological factors, a low mean value indicates that the factor was common among most entrepreneurs while for the environmental factors, it indicates that most entrepreneurs perceive the factor to significantly affect their business operations. The most common psychological factor possessed by most entrepreneurs was self-efficacy and the least as risk taking propensity. Access to finance and taxes were seen to be the factors that affect business operations the most.

\subsection{Factors affecting Growth Intentions}

Table 3: The determinants of growth intention

\begin{tabular}{lcc}
\hline & \multicolumn{2}{c}{ Growth Intention } \\
\cline { 2 - 3 } & Independent Variable & T-Stat \\
\hline Intercept & & 15.478 \\
Gender & -0.051 & -1.112 \\
Prior Experience & 0.001 & 0.029 \\
Prior family business exposure & 0.097 & $1.988^{\star *}$ \\
Level of education & 0.092 & $1.975^{\star *}$ \\
Entrepreneurship Education & 0.105 & $2.194^{\star *}$ \\
Startup motives & -0.024 & 0.499 \\
Need for achievement & 0.148 & $2.100^{\star *}$ \\
Locus of control & 0.194 & $2.948^{\star \star *}$ \\
Risk Taking Propensity & 0.070 & 1.334 \\
Tolerance of Ambiguity and Uncertainty & 0.139 & $2.341^{\star *}$ \\
Self-efficacy & 0.386 & $6.078^{\star * *}$ \\
Access to finance & -0.111 & $-1.733^{*}$ \\
Procedural requirements for registration & -0.099 & $-2.069^{\star *}$ \\
Taxes & -0.012 & -0.177 \\
R2 & & 0.623 \\
Adjusted R2 & & 0.594 \\
F-value & & 21.810 \\
Durbin-Watson stat & & 2.108 \\
\hline
\end{tabular}

*** Significant at 1\%; ** Significant at 5\%; * Significant at 10\%

The results on Table 3 show the internal and external factors that determine the level of growth intentions among entrepreneurs. These factors were jointly used in a regression analysis because prior studies (Mappigau \& Maupa, 2013; Shane \& Khurana, 2003) have established that a combination of these factors influence the entrepreneur's decision to start and grow a business. Locus of control and self-efficacy are significant at the $1 \%$ level, while prior family business exposure, level of education, entrepreneurship education, need for achievement, tolerance of ambiguity and uncertainty and procedural requirements for business registration are significant at the $5 \%$ level. These findings are consistent with prior studies (Torres \& Watson, 2013; Li \& Lo, 2012); however, some significant differences are also noted between these findings and those of prior studies. For example, some studies by (Torres \& Watson, 2013; Li \& Lo, 2012) found a positive relationship between self-efficacy and growth intentions of entrepreneurs. Crant (1996) also found a positive relationship between family exposure to business and growth intentions of the entrepreneur. Similar to the findings of Karadeniz and Ozçam (2010) and Fatoki (2013), this study also found a positive relationship between level of education and growth intention; however no significant relationship was identified with regards to gender as established by Ozcam (2010). Fatoki (2013) also found no significant relationship between gender and growth intentions. This possibly continues the debate with regards to the role of gender in growth intentions as Levie and Autio (2013) established that gender showed no consistent relationship with growth intentions. Contrary to Levie and Autio (2013), risk taking propensity was seen to have no significant relationship with growth intentions. This study also established no significant relationship between start-up motives and growth ambitions which is contrary to the findings of Fatoki (2013) who found a significant positive relationship between these two variables.

Factors like locus of control and entrepreneurship education has mostly been attributed to an entrepreneur's intention to starting a new business (Ayodele, 2013; Ferreira, Raposo, Rodrigues, Dinis, Paço, 2012). However, Torres 
and Watson (2013) argue that the entrepreneurial process does not end with starting the business but also incorporates the intention to grow the business. This view can be supported by these findings as it indicates that factors like locus of control and entrepreneurship education which have been known to significantly influence the intention to start a business also have a significant influence on the growth intentions of entrepreneurs.

\subsection{Relationship between Growth Intentions and Actual SME Growth}

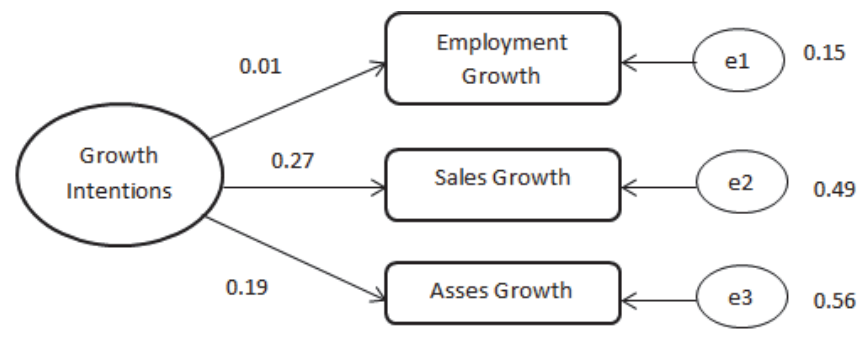

Figure 2: Structural Equation Model Path Diagram between the Dependent Variables SME Growth (Employment Growth, Sales Growth, and Asset Growth) and Independent Variables (growth intention)

The SEM path diagram in Figure 2 indicates the different path coefficients explaining the relationship between the different components of SME growth and growth intention. The positive path coefficients indicate a positive relationship between growth intention and the respective components of SME growth. This shows that as the growth intention of an SME increases, it's potential to grow in terms of employment, sales growth, and asset growth also increases. The significance of each of the relationships established in the path diagram is indicated in Table 3 below.

Table 4: Casual relationships for Structural Equation Model based on SMEs growth and Growth intention

\begin{tabular}{|lll|c|c|c|c|}
\hline & & & Parameter Estimate & Standard Error & Critical Ratio & P - Value \\
\hline Employment Growth & $<-------$ & Growth Intention & 0.003 & 0.002 & 1.582 & 0.114 \\
\hline Asset Growth & $<------$ & Growth Intention & 0.206 & 0.027 & 7.679 & $\star \star \star$ \\
\hline Sales Growth & $<-------$ & Growth Intention & 0.174 & 0.031 & 5.632 & $\star \star \star$ \\
\hline
\end{tabular}

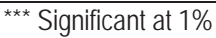

The results in Table 4 show the casual relationship based on the components of SME growth and growth intention. The results indicate that growth intention has a significant causal relationship with sales growth and asset growth, thus depicting that the growth intention of the entrepreneur determines the actual growth potential of the business. Also, observed is that growth intention has no significant relationship with employment growth. This confirms to the study by Kolvereid, (1992) who established that although entrepreneurs want to grow their firms in terms of sales; they do not necessarily want to grow in terms of employees. As such, the specific component used in measuring firm growth is important when establishing how growth intentions affect actual growth. These findings are similar with some prior studies (Delmar \& Wilkund, 2008; Stenholm, 2011); however, there are also some notable differences with some prior studies (Kolvereid \& Bullvag, 1996; Delmar \& Wilkund, 2008) that require further discussion. Prior studies (Kolvereid \& Bullvag, 1996; Delmar \& Wilkund, 2008; LeBrasseur, Zanibbi \& Zinger, 2003; Stenholm, 2011) that measured actual growth in terms of sales growth found a significant relationship growth intentions and actual firm growth. Prior studies (Shepherd and Wiklund 2009; Isaga, 2012; Achtenhagen, Naldi \& Melin, 2010) have indicated that most entrepreneurs measure their firm growth in terms of the growth in sales. As such, intentions to grow the business are more likely backed by strategies for increasing the sales turnover of the business as Levie and Autio (2013) highlight that achieving growth requires efforts which entrepreneurs need to ensure their growth intentions materialize. Jansen (2009) explicate that it is the increase in sales that makes it possible for businesses to invest in additional factors of production such as equipment and employee, which will in turn result in raising the profits of the business. The significant relationship between growth intentions and asset growth is also a valuable contribution to prior studies (Shepherd \& Wilkund, 2008; Sirec \& Mocnik, 2010; Lee, Lee \& Lee, 2003; Covin \& Slevin, 2000) that measure SME growth in terms of asset growth but, however, did not relate it to growth intentions. Also, Wilkund and Shepherd (2003) argue that growth is unlikely to occur without the 
necessary assets such as financial resources even if the entrepreneur has growth intentions.

The finding with regards to employment growth is contrary to prior studies (Kolvereid \& Bullvag, 1996; Delmar \& Wiklund, 2008; Stenholm, 2011) which have indicated a significant relationship between growth intentions and employment growth. A common factor between these studies is that they were all carried out in Scandinavian countries (Norway, Sweden, and Finland) which have relatively lower unemployment rates (3.4\% for Norway, $7.9 \%$ for Sweden, and $8.1 \%$ for Findland) 1 when compared to that of South Africa which has a high unemployment rate which is currently estimated at 24.1\% (Statistics South Africa, 2014). Delmar \& Wiklund (2008) argue that SMEs can grow by increasing sales while outsourcing production, thus resulting in a marginal effect on sales growth but not on employment growth. It is possible that such SME growth dynamics could be prevailing in the South Africa SME sector thus explaining why the SME sector is failing to absorb the high number of unemployed people in the country. Also, the lack of skills has been identified as a key factor contributing to the high failure rate of SMEs in South Africa (Herrington, Kew \& Kew, 2009) thus providing no incentive for entrepreneurs to employ unskilled workers given that the high unemployment rate is South Africa is mostly among the unskilled people (Neneh \& Smit, 2013). However, with the recent tax incentives for employment of unskilled youths in South Africa, the dynamics might change in the near future with SMEs increasing employment in order to benefit from tax cuts.

\section{Conclusion}

This paper examined the factors that determine the growth intention amongst existing business owners and the impact growth intention has on the actual SME growth. Understanding the factors that affect the growth intentions of entrepreneurs is important as prior studies have associated an entrepreneur's intention to grow a business with the actual growth of the business. This study identified a number of internal factors and external environmental factors that significantly affect the growth intentions of entrepreneurs in South Africa. This study also established that growth intentions were significantly related to actual firm growth in terms of sales growth and asset growth. These findings can be useful in developing support programs that will promote a culture of growth oriented thinking amongst SMEs owners as a means of foster growth in the SME sector. This is because most SMEs in South Africa fail before achieving any level of growth and maturity (Fatoki and Garwe, 2010; Herrington, 2010). Herrington (2010) found that only 1\% of all newly established SMEs grow and survive for longer than one year. Fatoki and Garwe, (2010) established that most SMEs in South Africa do not move from the first stage (existence) of growth to other stages such as survival, success, take off and resource maturity.

Moreover, the fact that growth intentions have no significant relationship with employment is a call for concern as the country is highly depending on the SME sector to create the much needed jobs. This possibly provides some valuable information on how entrepreneurs in South Africa chose to grow their businesses. It is however not surprising that the growth intentions are more associated with sales growth and asset growth as entrepreneurs have been noted to mostly measure their growth in terms of sales growth. To address the high unemployment rates, government needs to provide incentives for these SMEs that grow in terms of sales and assets to also increase their number of employees. The recently started (as of January 2014) tax incentive introduced by the South African government for employing unskilled workers could be a possible solution on addressing this issue, but, nevertheless, the impact of such a program will only be known in the near future.

\section{References}

Achtenhagen, L., L. Naldi., \& L. Melin (2010). Business Growth: Do Practitioners and Scholars Really Talk About the Same Thing? Entrepreneurship Theory and Practice 34(2), 289-316.

Agbim, C.K., Oriarewo, O.G., \& Owocho, M. (2013). Factors influencing entrepreneurial intentions among graduates of Nigerian tertiary institutions. International Journal of Business and Management Invention, 2(4), 36-44.

Ajzen, I. (1991). The theory of planned behavior. Organizational Behavior and Human Decision Processes, 50: 179-211.

Autio, E. (2007). Global Entrepreneurship Monitor 2007. Global Report on High-Growth Entrepreneurship. London: Global Entrepreneurship Research Association.

Autio, E., Keeley, R. H., Klofsten, M., Parker, G. G. C., \& Hay, M. (2001). Entrepreneurial Intent among Students in Scandinavia and in the USA. Enterprise \& Innovation Management Studies, 2(2), 145-160.

Ayodele, K.O. (2013). Demographics, Entrepreneurial Self-Efficacy and Locus of Control As Determinants Of Adolescents'

\footnotetext{
1 Unemployment rates for Norway, Sweden and Finland are data for October 2013 published by the European Commission. [Online]: http://epp.eurostat.ec.europa.eu/statistics_explained/index.php/Employment_statistics
} 
Entrepreneurial Intention In Ogun State, Nigeria. European Journal of Business and Social Sciences, 1(12),59-67

Blackburn, R., Kitching, J., Hart, M., Brush, C., \& Ceru, D. (2008). Growth Challenges for Small and Medium-sized Enterprises: A UK-US Comparative Study. UK Treasury and BERR Report URN 09/683.

Block J.H., \& Sandner, P. (2009). Necessity and opportunity entrepreneurs and their duration in self-employment: evidence from German Micro Data. Journal of Industry, Competition and Trade, 9 (2), 117-337.

Bosma N, Van Praag M., \& De Wit, G. (2000). Determinants of Successful Entrepreneurship. [Online] available: <http://www1. feb.uva.nl/pp/bin/nonrefereedbook publication525fulltext.pdf> (Retrieved on 15 June, 2013).

Cassar, G. (2007). Money, money, money? A longitudinal investigation of entrepreneur career reasons, growth preferences and achieved growth. Entrepreneurship and Regional Development 19, 89-107.

Covin, J.G., \& Slevin, D.P. (2000). Pioneers and followers: Competitive tactics, environment, and firm growth. Journal of Business Venturing, 15(2), 175-211.

Crant, M. (1996). The proactive personality scale as a predictor of entrepreneurial intentions. Journal of Small Business Management, 5 , 131-142.

Davidsson P., L. Achtenhagen., \& L. Naldi. (2010). Small firm growth. Found and Trends in Entrepreneurship 6(2), 69-166.

Davidsson, P. (1989). Entrepreneurship and after? A study of growth willingness in small firms. Journal of Business Venturing, 4, $211-$ 226.

Delmar, F., \& Wiklund, J. (2008). The Effect of Small Business Managers' Growth Motivation on Firm Growth: A Longitudinal Study. Entrepreneurship: Theory \& Practice, 32(3): 437-457.

Department for Business, Innovation \& Skills HM Treasury. (2014). Making it easier to set up and grow a business. [Online] available: https://www.gov.uk/government/policies/making-it-easier-to-set-up-and-grow-a-business- -6 (April, 14th, 2014).

Dobbs, M., \& R.T. Hamilton (2007). Small Business Growth: Recent Evidence and New Directions. International Journal of Entrepreneurial Behaviour \& Research, 13 (5), 296-322.

Dutta, D.K., \& Thornhill, S. (2008). The evolution of growth intentions: toward a cognition-based model. Journal of Business Venturing, 23, 307-332.

Fairlie, W. R. (2009). Kauffman index of entrepreneurial activity 1996-2008, Kauffman Foundation.

Fairlie, W.R. (2009). Kauffman index of entrepreneurial activity 1996-2008. Kauffman Foundation.

Fatoki, O., \& Garwe, D. (2010). Obstacles to the growth of new SMEs in South Africa: A principal component analysis approach. African Journal of Business Management, 4(5), 729-738.

Fatoki, O.O. (2010). Graduate Entrepreneurial Intention in South Africa: Motivations and Obstacles. International Journal of Business and Management, 5(9), 87-98.

Fatoki, O.O. (2013). The Determinants of Immigrant Entrepreneurs' Growth Expectations in South Africa. Journal of Social Science 37(3), 209-216.

Ferreira, J.J., Raposo, M.L., Rodrigues, R.G., Dinis, A., \& Paço, A. (2012). A model of entrepreneurial intention: An application of the psychological and behavioral approaches. Journal of Small Business and Enterprise Development, 19(3), 424 - 440.

Fini, R., Grimaldi, R., \& Sobrero, M. (2009). Factors Fostering Academics to Start up New Ventures: an Assessment of Italian Founders' Incentives. Journal of Technology Transfer, 34, 380-402.

Fishbein, M., \& Ajzen, I. (1975). Belief, Attitude, Intention and Behavior. An Introduction to Theory and Research, Reading, MA: Addison-Wesley.

George, D., \& Mallery, P. (2003). SPSS for windows step by step: A simple guide and reference. 11.0 update (4th ed.). Boston: Allyn \& Bacon

Gundry, L.K., \& Welsch, H.P. (2001). The ambitious entrepreneur: High growth strategies of women-owned enterprises. Journal of Business Venturing, 16, 453-470.

Herrington, M., Kew, J., \& Kew, P. (2009). Global Entrepreneurship Monitor, South African report. [Online] available: http://www. gbs.nct.ac.za /gbswebb/userfiles/gemsouthafrica2000pdf

Hisrich, R.D., \& Drnovsek, M. (2002). Entrepreneurship and small business research. Journal of Small Business and Enterprise Development, 9, 172-222.

Isaga, N. (2012). Entrepreneurship and the growth of SMEs in the furniture industry in Tanzania". Doctorates dissertation.[Online] available: http://dare .ubvu .vu.nl/bitstream/handle/1871/35483/chapter_all_chapters.pdf?sequence=2

Jansen, F. (2009). The conceptualisation of Growth: Are Employment and Turnover Interchangeable Criteria? Journal of Entrepreneurship, 18(1), 21-45.

Karadeniz. E., \& Ozcam, A. (2010). The determinants of the growth expectations of The Early-stage Entrepreneurs (TEA) using the Ordinal Logistic Model (OLM): The case of Turkey. Economics and Business Review,12(1), 61-84.

Kolvereid, L. (1992). Growth aspirations among Norwegian entrepreneurs. Journal of Business Venturing 7, $209-222$.

Kolvereid, L., \& Bullvag, E. (1996). Growth intentions and actual growth: the impact of entrepreneurial choice. Journal of Enterprising Culture, 4(1),1-17

Krueger, N.F. (2000). The cognitive infrastructure of opportunity emergence. Entrepreneurship Theory and Practice, 24, 5-23.

Krueger, N.F., Reilly, M.D., \& Carsrud, A.L. (2000). Competing models of entrepreneurial intentions. Journal of Business Venturing, 15, 411-432

Lee, J., Lee, J., \& Lee, H. (2003). Exploration and exploitation in the presence of network externalities. Management Science, 49(4), 553-571 
Lee, S.M., Chang, D., \& Lim, S.B. (2005). Impact of entrepreneurship Education: A Comparative Study of the U. S. and Korea. International Entrepreneurship and Management Journal, 1, 27-43.

Levie, J., \& Autio, E. (2013). Growth and growth intentions: A meta-analysis of existing evidence. Enterprise Research Centre (ERC) White Paper No.1. [Online] available: http://enterpriseresearch.ac.uk/default/assets/File/ ERC\%20White\%20Paper\%20No 1\%20Growth\%20final.pdf.(May,7th ,2014).

Levratto, N., Tessier, L., \& Zouikri, M. (2010). The determinants of growth for SMEs. A longitudinal study of French manufacturing firms. [Online] available: http://ssrn.com/abstract=1780466 or http://dx.doi.org/10.2139/ssrn.1780466 (February, 15th, 2014).

Li, P.H.Y., \& Lo, C.W.H. (2012). The Prediction Of Entrepreneurs' Strategic Growth Intentions By General Self-Efficacy (GSE) Versus Entrepreneurial Self-Efficacy (ESE) (Interactive Paper), Frontiers of Entrepreneurship Research, 32(5), Article 24.

Malebana, J. (2014). Entrepreneurial intentions of South African rural university students: A test of the theory of planned behaviour. Journal of Economics and Behavioral Studies, 6(2), 130-143.

Mappigau, P., \& Maupa, H. (2013). Entrepreneurial Intention and Small Business Growth: An Empirical Study of Small Food Processing Enterprises in South Sulawesi, Indonesia. International Journal of Business and Social Research (IJBSR), 2 (4),237-248.

Mazanai, M., \& Fatoki, O.O. (2011). The Effectiveness of Business Development Services Providers (BDS) in Improving Access to Debt Finance by Start-Up SMEs in South Africa. International Journal of Economics and Finance, 3 (4), 208- 216.

Mthente Research and Consulting Services. (2012). Analysis of the Needs, State and Performance of Small and Medium Businesses in the Agriculture, Manufacturing, ICT and Tourism Sectors in South Africa. Small Enterprise Development Agency (SEDA). [Online] available:http://www.seda.org.za/Publications/Publications/Analysis\%20of\%20the\%20needs,\%20State\%20and\%20Performance \%20of\%20Small\%20and\%20Medim\%20Businesses\%20in\%20the\%20Agriculture,\%20Manufacturing,\%20ICT\%20and\%20Touri. pdf (April, 14th ,2014).

Neneh, B.N., \& Smit, A.A. (2013). Will promoting more typical SME start-ups increase job creation in South Africa? African Journal of Business Management, 7(31), 3043-3051.

Neneh, B.N., \& Vanzyl, J. (2012). Achieving optimal business performance through business practices: evidence from SMEs in selected areas in South Africa. Southern Africa Review, 16(3), 118-144.

Orser, B., Hogarth-Scott, S., \& Riding, A.L. (2000). Performance, firm size, and management problem solving. Journal of Small Business Management 38 (4), 42-58.

Papadaki, E., \& Chami, B. (2002). Growth Determinants of Micro-Businesses in Canada, Ottawa: Industry Canada Small Business Policy Branch.

Sadeghi, M., Mohammadi, M., Nosrati, M., \& Malekian, K. (2013). The Role of Entrepreneurial Environments in University Students Entrepreneurial Intention. World Applied Programming, 3(8),361-366.

Sadler-Smith, E., Hampson, Y., Chaston, I., \& Badger, B. (2003). Managerial Behaviour, Entrepreneurial Style, and Small Firm Performance. Journal of Small Business Management, 41(1), 47-67.

Scheepers, M.J., Solomon, G., \& de Vries, A. (2009). Entrepreneurial Intentions and Behaviour of South African University Students. Global University Entrepreneurial Spirit Students' Survey: South African Report 2008-2009. University of Stellenbosch. [Online] available: http://www.guesssurvey.org/PDF/2009/Guesss_SACountryReport_Final08_09.pdf.

Sexton, D. L. (1997). Entrepreneurship research needs and issues. In D. L. Sexton \& R. W. Smilor (Eds.), Entrepreneurship 2000 (pp. 401-408). Chicago, IL: Upstart Publishing Company.

Shane, S., \& Khurana, R. (2003). Bringing individuals back in: the effects of career experience on new firm founding. Industrial and Corporate Change, 12(3), 519-543.

Shepherd, D., \& Wiklund, J. (2009). Are We Comparing Apples With Apples or Apples With Oranges? Appropriateness of Knowledge Accumulation across Growth Studies. Entrepreneurship: Theory \& Practice, 33(1), 105-123.

Sirec, K., \& Mocnik, D. (2010). How entrepreneurs' personal characteristics affect SMES' growth. Our Economy/Nase Gospodarstvo, 56 (1/2), 3-12.

Statistics South Africa. (2014). South Africa Unemployment Rate. [Online] available: http://www.tradingeconomics.com/ south-africa lunemployment-rate. ( February,14th, 2014.

Stenholm, P. (2011). Innovative Behaviour as a Moderator of Growth Intentions." Journal of Small Business Management, 49(2), 233251.

Tan, W.L., Menkhoff, T., \& Chay, Y.W. (2007). The Effects of Entrepreneurial Growth Orientation on Organizational Change and Firm Growth, Research paper series Volume 1207, Lee Kong Chian School of Business, Singapore Management University.

Terjesen, S., \& Szerb, L. (2008). Dice thrown from the beginning? An empirical investigation of determinants of firm level growth expectations. Estudios thrown de Economía, 35(2), 153:178.

Toivonen, J., Stenholm, P., \& Heinonen, J. 2006. Different Conditions of Growth," in the Nature and Elements of Growth—Finnish SMEs in Focus. Ed. J. Heinonen. Turku: Turku School of Economics, 122-137.

Tomlin, B. (2008). Clearing hurdles: key reforms to make small businesses more successful. (Commentary No. 264). Toronto, Ontario C.D. Howe Institute. [online], available www.cdhowe.org/pdf/commentary_264.pdf. [April, 16th, 2014.

Torres, N.J.L. \& Watson, W. (2013). An Examination of the Relationship between Manager Self-Efficacy and Entrepreneurial Intentions and Performance in Mexican Small Businesses. Contaduria Y Administracion, 58(3), 65-87.

Tshikovhi, N., \& Shambare, R. (2012). Entrepreneurship Intentions of Students in Free Enterprise at Tshwane University of Technology. Tshwane University of Technology. [Online] available :http://newbizzjournal.com/2012/12/entrepreneurship-intentions-ofstudents-in-free-enterprise-at-tshwane- university-of-technologyl 
Van Gelderen, M., Brand, M., van Praag, M., Bodewes, W., Poutsma, E., \& van Gils, A. (2008). Explaining entrepreneurial intentions by means of the theory of planned behaviour. Career Development International, 13(6), 538-559.

Verheul, I., \& van Mil, L. (2008).What determines the Growth Ambition of Dutch Early-Stage Entrepreneurs? Scientific Analysis of Entrepreneurship and SMEs (SCALES) initiative. [Online] available: http://www.entrepreneurship-sme.eu/pdf-ez/H200811.pdf. (April, 20th, 2014).

Verheul, I., Thurik, R., Grilo, I., \& van der Zwan, P. (2012). Explaining preferences and actual involvement in self-employment: gender and the entrepreneurial personality. Journal of Economic Psychology, 33 (2), 325-341.

Vivarelli, M. (2004). Are all the potential entrepreneurs so good? Small Business Economics, 23(1), 41-49.

Vroom, V.H. (1964). Work and Motivation. New York: John Wiley.

Welsch, H., Price, P. D., \& Stoica, M. (2013). Innovation, Performance and Growth Intentions in SMEs. International Journal of Economics and Management Engineering (IJEME), 3 (5), 176-181.

Wiklund, J., \& Shepherd, D. (2003). Aspiring for, and Achieving Growth: The Moderating Role of Resources and Opportunities. Journal of Management Studies 40(8), 1919-1941.

Wiklund, J., Davidsson, P., \& Delmar, F. (2003). What do they think and feel about growth? Entrepreneurship: Theory and Practice, 27 (3), 247-269.

Yeboah, A.S., Kumi, E., \& Baffour A.J. (2013). An Assessment of Entrepreneurship Intention among Sunyani Polytechnic Marketing Students. International Review of Management and Marketing, 3(1), 37-49.

Zapalska, A., Dabb, H., \& Perry, G. (2003). Environmental factors affecting entrepreneurial activities: Indigenous Maori entrepreneurs of New Zealand. Asia Pacific Business Review, 10(2), 160-177. 